\title{
UTHM Muslim Students Proficiency on the Ahl Sunnah Wal Jamaah Background, Characteristics and Aqeedah Methodologies
}

\author{
Shakila Ahmad ${ }^{a}$, Sharifah Khadijah Syed Abu Bakar', Harliana Abd. Halimc, Intan Farhana \\ Saparuddin $^{\mathrm{d}}$, Abdullah Sulaiman ${ }^{\mathrm{e}}$, Halimi Mohd. Khalid ${ }^{\mathrm{f}}$, Nur Zainatul Nadra Zainol ${ }^{\mathrm{g}}$, and Siti \\ Marpuah $^{\mathrm{h}}$ \\ Senior Lecturer, Centre for General Studies and Co-curriculum, Universiti Tun \\ Hussein Onn Malaysia, 86400 Parit Raja, Batu Pahat, Johor. \\ $\mathrm{B}, \mathrm{c}, \mathrm{d}, \mathrm{e}, \mathrm{f}, \mathrm{g}, \mathrm{h}$ \\ Lecturers, Centre for General Studies and Co-curriculum, Universiti Tun Hussein Onn Malaysia, 86400 Parit Raja, Batu Pahat, \\ Johor.
}

Article History: Received: 11 January 2021; Accepted: 27 February 2021; Published online: 5 April 2021

\begin{abstract}
Ahl Sunnah Wal Jamaah (ASWJ) is a name given to a dominant group of Muslims who adhere to the teaching brought by Rasullah SAW and his companions. In Malaysia, ASWJ Asyai'rah has its place in the main stream and is being used in Islamic education modules at all levels of studies starting from pre-school up to secondary school. As a result it has been able to create uniformity and harmony in Muslim students way of thought when they are at tertiary level. It is expected that all Muslim students undergo a formal education process about ASWJ background, characteristics and methodologies that are used in aqeedah discussion. The article is intended to explain a research pertaining to Universiti Tun Hussein Onn Malaysia muslim students proficiency towards ASWJ background, characteristics and methodologies used in discussing aqeedah. A total of 236 diploma students were involved in the study. At the time of the study, the students were undertaking Introduction of Islamic Studies (UQI10402) course that was offerred by the Department of Islamic Studies, Centre for General Studies and Co-curriculum during a special semester. Students were required to respond to 20 items serving as indicators on ASWJ background, characteristics and methodologies. 5 points likert scales were employed in the Google Form survey. The findings indicates a very high level of students proficiency on the ASWJ backgrounds and characteristics (mean=4.620). However, upon anlysis there are four items in methodologies indicating a high level of proficiency(mean=3.915 to 4.169). The findings is hoped to give valuable information to the related authorities in strengthening the ASWJ aqeedah module namely; UTHM Islamic Centre, Ahl Sunnah Wal Jamaah Institute,UTHM, UTHM General Studies and Johor Islamic Council.
\end{abstract}

Keywords: Background. Characteristics, Ahl Sunnah Wal Jamaah Methodologies.

\section{Introduction}

Ahl Sunnah Wal Jamaah ASWJ is a name given to a majority of Muslims that follow the teaching of the Prophet SAW and his companions. The Yemenite preachers brought ASWJ aqeedah to the Malay Peninsular. The ASWJ (Asyairah) aqeedah has been used widely and become the official denomination in Malaysia up to the present day. It is being conceptualized through practices, education and enforcement of law ((Adam Badhrulhisham, 2016).

Mohd Shafiee (2015) emphasized that the implementation of the element of aqeedah is fundamental in the formation of Malaysian education policies especially in the National Education Policy which is known as the pillar of Malaysian education system. According to Khairi Jalalluddin (2019) the ASWJ Asyairah based education are conducted at pre, primary and secondary education level. Thus, the proficiency in ASWJ aqeedah is very significant because the education at tertiary level is more open as issues other than ASWJ aqeedah will also be discussed.

At UTHM, Muslim students at diploma level are required to enrol in Introduction to Islamic Studies as a compulsory course. The syllabus briefly discusses topics within ASWJ, namely; definition, history, salaf and khalaf along with ASWJ manhaj. The topics covered served as a reinforcement from what they had learnt at secondary school level ( Introduction to Islamic Studies Syllabus, UTHM)

To which extent do the Muslim students master the ASWJ aqeedah after they have gone through a substantial amount of education process? Therefore, this research was conducted to determine the level of students' proficiency level in ASWJ learning. A measuring instrument was developed based on the content of ASWJ teaching in Malaysia with references that were sourced from books and journals. In addition to fill gap within the issue, the findings from the measurement are able to assist the efforts in reinforcing ASWJ aqeedah that are conducted by JAKIM, States Islamic Council and NGO. This working paper will further discuss the findings on students' proficiency towards ASWJ background, characteristics and methodologies 
In short, ASWJ adherents are characterized by a greater emphasis upon the Islamic traditions practiced by Prophet Muhammad SAW and his companions ((K.H Sirajuddin, 2016). On the other hand, JAKIM the authorizing body that governs matters pertaining to Islam defines ASWJ as the adherents that firmly observing the Al Quran and Sunnah through the taching of the companions (sahabah), tabiin and tabi tabiin whilst being loyal in matters regarding aqeedah,jurispundence and morals. (Adam Badhrulhisham, 2016).

Muhyiddin Abdul Somad (2009), explained Al-Sunnah within the ASWJ phrase proposes the teaching of the Prophet SAW in the forms of practices, speech and confession. Meanwhile, the word Al-Jamaah conveys the agreement among the companions during the reign of Khulafa al-Rasyidin namely; Caliph Abu Bakar RA, Umar bil al-Khattab RA, Uthman bin Affan RA dan Ali bin Abi Talib RA

Among the discussion on the background of ASWJ is based on the hadith narrated by Abdullah bin Amru,

ليأتين على أمتي ما أنى على بني إسر ائيل حذو النعل بالنعل حتى إذا كان منهم من أنى أمه علانية لكان في أمتي من يصنع ذلانك و إن بني إسر ائيل

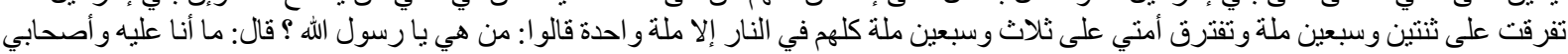

It will happen to my ummah as how it was ensued upon the Bani Israel, like a pair of sandals, when there were among them who explicitly had intercourses with their own mothers, there are among my ummah who will similarly do the same act. Indeed, the Bani Israel had been divided into 72 fractions while my ummah will split into 73 sects, which all will enter the hellfire but one" the companions asked: who are among that group o Rasullah? The prophet answered: "Those who follow my path and my companions"

Al-Baghdadi (2013) elaborated that there are 72 deviated groups, he further reiterated the 73rd group is the group that will head to paradise is the adherents of ASWJ whom are of the people who agreed upon the oneness of Allah SWT, in terms of His nature and names, prophecies, avoiding tasybih and ta'til as well as believing in the holy books.

In reference with the discussion of ASWJ definition, it has been understood that ASWJ was founded by the companions guided by the teaching of Prophet SAW ((Johari Mat, t.t.) and the name was used amongst the companions (Engku Ahmad Zaki, t.t.) in the early of the first century. Engku Ahmad Zaki (t.t.) also reviewed other titles which are linked with ASWJ; the majority (Sawad al-A'zam), Ahli Hak (Ahl al-Haq) and the successfuls (al-Firqah al-Najiyah) (al-Baghdadi, 2013).

Zakaria Stapa (2015), Abdul Hamid Yunus (2005) and Adam Badrulhisham (2016) proposed ASWJ definition as a demonstration of initial identity of which a dominant group among the Muslims within multidisciplinary areas whose practices obey Allah SWT and observe the teaching of the Prophet SAW and his companions.

ASWJ emphasizes on the unity and harmony in practicing wasatiyyah concept in aqeedah in line with the Islamic faith (Adam Badrulhisham, 2016). Mohd. Aizam (2015), summarized the wasatiyyah concept in aqeedah based on manhaj employed by Abu Hasan al-Asy'ari encompassing the definition of faith, aqeedah sources, approach in aqeedah, matters in divinity, prophecies and unseen.

In Malaysia, the Muslims are united through the ASWJ aqeedah Imam Al-Asy'ari, Syafiie school of thought (Islamic jurispundence) and Imam Al-Ghazali ethical and spiritual ideals. There are several states that officially acknowledged ASWJ as an official denomination (Zakaria Stapa, 2015). This uniformity promotes harmonious living among muslims besides leaving positive impact in political matters and admeanistration.

Sirajuddin (2016, 2-3), asserted that the aqeedah brought by Prophet SAW and his companions are as recorded in the al-Quran and al-Sunnah. The guides then were compiled by Islamic thoughts prominent scholars; Imam Abu al Hasan "Ali al-Ay'ari and Imam Abu Mansur al-Maturidi. Imam Abu Hasan al-Asy'ari was born in Bashran in $260 \mathrm{H}$ and died in $342 \mathrm{H}$. His disciples are known as al- 'Asya'irah. Meanwhile, Imam Abu Mansur al-Maturidi was born in Maturid, Samarkand, Uzbekistan and died in 333H. His disciples are recognised as al-Maturidiah. They had compiled the Tauhidic knowledge which contents had been written in books like al-Ibanah `an Usul alDiyanah dan Maqalat al-Islamiyyin, Kitab al-Tauhid and Ta'wilat Ahl al-Sunnah (Muhyiddin Abd Somad, 2009). The same school of thought had become the guidelines and observed by Malaysian Muslims, Islamic aqeedah compiled by Imam Abu Hasan al-'Asy'ari which shows a great distinction between the astrays and heretics.

Malaysian Muslims should know the background of ASWJ including the two prominent meritorious namely, Abu Hasan al-Asy'ari and al-Maturidi, so that one's life is more directed. Striving to be part of ASWJ is a goal in order to be safe in the world and in the hereafter. Hence, mastering it can also differentiate one's faith, practices and good moral conducts.

The main characteristics of ASWJ is to have faith with the six articles of faith and to consistently observe the five pillars of Islam. Khairul Hamimah (2008), put a theme in aqeedah understanding for her research in Private Institution Students Proficiency in Islamic Aqeedah and Its Effects towards Morals. Amongst the important items included were aqeedah, knowledge of faith articles and pillars of Islam, understanding on intention (niyyah), prostration (sujud), , takbiratul ihram and tahiyah in prayer. Her research indicated that a significant number of students denoted that they did not understand the meaning of Islamic aqeedah. In addition to that they were also not aware of the differences between aqeedah and moral. It is even more worrying when there had been students who did not give a correct answer about the Articles of Iman and Pillar of Islam. The findings from the two items; the meaning of aqeedah and knowledge about the Articles of Iman and Pillar of Islam signifies a concerning level 
of proficiency towards ASWJ aqeedah. Hence, the paramount need of a detailed research in students proficiencyof ASWJ aqeedah.

Rasulullah SAW morals are observed by ASWJ which in return making those who believe be the best ummah (Muhammad Abd al-Hadi, 1998) through enjoining good and forbidding wrong, this is in parallel with these following verse form Surah Al Imran 110:

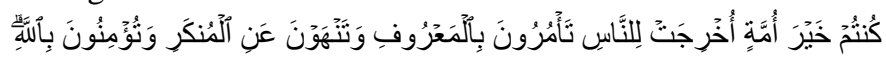

You are the best community ever raised for humanity—you encourage good, forbid evil, and believe in Allah. Had the People of the Book believed, it would have been better for them. Some of them are faithful, but most are rebellious.

As far as ASWJ methodology is concerned, in Malaysia, it is guided by the manhaj formed by Abu Hasan al-Asy`ari. The research methods for this study have been divided into three parts, the use of revealation and intellect (aql), the understanding of Al-Quranic verses and ambiguous (mutasyabihat) Hadith and a face to face session with the heretics.

In addition to introducing the methodology for a comprehensive aqeedah research, Al-Asya'irah also managed to highlight the role of aql as a tool to understand aqeedah by linking it to the argument from revelation through intellectual thinking. Thus, al-Asya'irah forefronts the approach in understanding ambiguous verse by using takwil (without rejecting the tawfidh approach) in order to sanctify Allah SWT without going overboard that may cause slander and chaos( Hamidi Ismail, 2020) .

The discussion has thus far covered the background, characteristics and the ASWJ al Asya'irah stream aqeedah methodology. Definitely, the contents leading to details on ASWJ have been conveyed to students explicitly in the course of their studies. As far as this matter is concerned, there has been no research pertaining to students' level of proficiency in the background, characteristics and the ASWJ al Asya'irah stream aqeedah methodology right after they finished secondary school. Therefore, it is only reasonable for this research to be conducted among diploma students in UTHM.

\section{Research Methodology}

This research employed both qualitative nad quantitative methods. Qualitaive method was used to identify important items in developing measuring instrument through analyzing contents of books, journal and related documents. Namely, Al-Farq Bayn al-Firaq by Imam Abdul Qahir al Baghdadi, Ihya Ulum al-Din by Muhammad b. Muhammad al-Ghazzali, I'tiqad Ahusunnah Wal Jamaah by KH Sirajuddin Abbas, Sulamu al-Tauhid by Haji Zakaria bin Haji Ahmad Wan and Risalah tauhid by Abdul Ghani Yahya have greatly become the source of references of this research. In order to access data on students proficiency in the ASWJ background, characteristics and methodologies; 20 items were identified. The instruments had gone through the experts realibility and validity process. This process involving three experts in aqeedah appointed from Universiti Kebangsaaan Malaysia (UKM), Universiti Teknologi Malaysia UTM) and Universiti Sains Islam Malaysia (USIM) respectively. The quantitative method on the other hand, was utilised through the distribution of Google Form survey questionnaire. The research was done among Universiti Tun Hussein Onn Malaysia diploma students, of which during the time of the study were under taking Introduction to Islami Studies(UQI10402) course offered in special semester (session 2020/2021). A total of 236 students were involved in the study

The measurement of students' proficiency used the five likert scales; 1 point represents Very Disagree (VD), 2 - Disagree (D), 3- Not Sure (NS), 4-Agree (A) and 5-Very Agree (VA). There are five items related to students proficiency towards ASWJ background, five items on ASWJ characteristics and ten items concerning ASWJ methodologies. The elaboration on the mean score are gauged based on the education and social science statistical interpretation formulated by Alias Baba (1999) as in Table 1.

Table 1: Interpretation research mean in education and social sciencel (Alias Baba, 1999)

$$
\text { Mean Score Interpretation }
$$

\begin{tabular}{cc}
$1.00-1.80$ & Very Low \\
\hline $1.81-2.60$ & Low \\
\hline $2.61-3.40$ & Moderate \\
\hline $3.41-4.20$ & High \\
\hline $4.21-5.00$ & Very High
\end{tabular}

\section{Research Findings}

Part A is the respondents demographic data as listed in Table 2

Table 2: Respondents Demographics

\begin{tabular}{|c|l|l|c|c|}
\hline No. & \multicolumn{2}{|c|}{ Item } & No. & Percentage \\
\hline 1 & Gender & Male & 166 & 70.3 \\
\hline
\end{tabular}


Shakila Ahmad ${ }^{a}$, Sharifah Khadijah Syed Abu Bakar ${ }^{b}$, Harliana Abd. Halim ${ }^{c}$, Intan Farhana Saparuddin ${ }^{\text {, Abdullah }}$ Sulaiman $^{e}$, Halimi Mohd. Khalid ${ }^{f}$, Nur Zainatul Nadra Zainol ${ }^{g}$, and Siti Marpuah $^{h}$

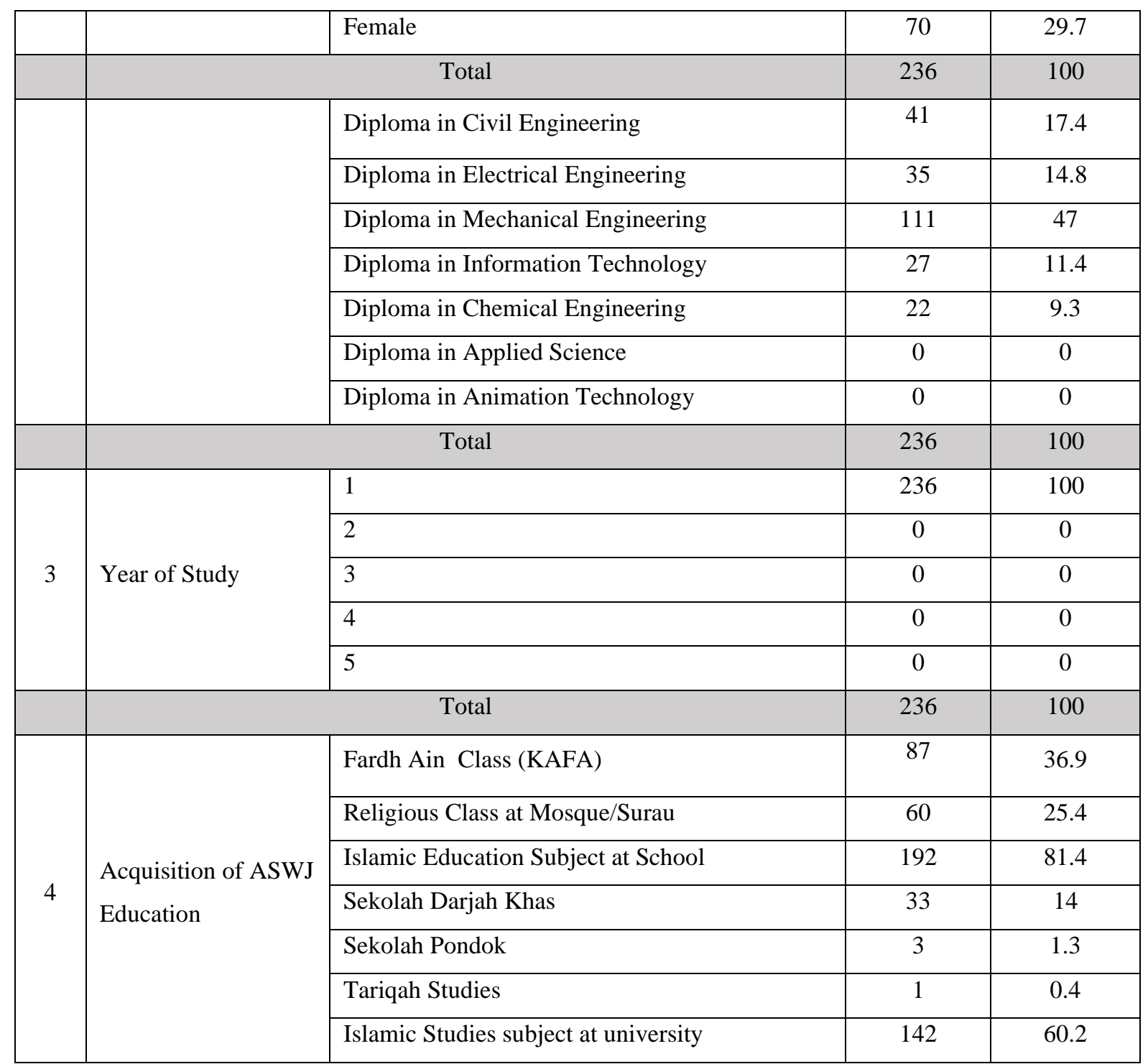

The research involved 236 respondents. Based on Table 1, the respondents comprised $166(70.3 \%)$ male students and 70 (29.75) female students. A total of 42 (17.4\%) students were from Civil Engineering Department, 35 (14.3\%) from Department of Electrical Engineering, 111 (47\%) from Department of Mechanical Engineering, $27(11.4 \%)$ from Department of Information Technology and 22 (9.3\%) from Department of Chemical Technology. All respondents, at the time of the research were first year students.

The research seeked to find out information regarding where did students get education about ASWJ aqeedah. Students could choose more than one options based on their individual education experience. 87(36.9\%) students studied ASWJ from Fardh Ain Class (KAFA), 60 (25.4\%) from Religious Class at Mosque/Surau , 192 (81.4\%) Islamic Education Subject at School, 33 (14\%) from Sekolah Darjah Khas, 3 (1.3\%) from Sekolah Pondok, 1 $(0.4 \%)$ from Tariqah Studies dan while a majority learned ASWJ 142 (60.2\%) from Islamic Studies subject at university.

Meanwhile Part B, represents the information on students' proficiency about ASWJ background and its characteristics. Table 3 shows a detailed information in the form of percentage. The overall mean score indicates a very high proficiency level; 4.62. Item 1-5 are related to the ASWJ background and overview. Item 6-10 listed the ASWJ important characteristics.

Table 3: Tabulation of students proficiency about ASWJ characteristics

\begin{tabular}{|c|c|c|c|c|c|c|c|c|}
\hline & Proficiency of ASWJ Background & $\begin{array}{c}\text { VD } \\
\%\end{array}$ & $\begin{array}{c}\text { D } \\
\%\end{array}$ & $\begin{array}{c}\text { NS } \\
\%\end{array}$ & $\begin{array}{c}\text { A } \\
\%\end{array}$ & $\begin{array}{c}\text { VA } \\
\%\end{array}$ & Mean & Interpretation \\
\hline 1 & $\begin{array}{c}\text { I know that ASWJ aqeedah complies } \\
\text { with the teaching of Rasulullah SAW } \\
\text { and majority of his companions }\end{array}$ & 0 & 0 & $\begin{array}{c}9 \\
3.8\end{array}$ & $\begin{array}{c}40 \\
16.9\end{array}$ & $\begin{array}{c}187 \\
79.2\end{array}$ & 4.754 & Very High \\
\hline
\end{tabular}


UTHM Muslim Students Proficiency on the Ahl Sunnah Wal Jamaah Background, Characteristics and Aqeedah Methodologies

\begin{tabular}{|c|c|c|c|c|c|c|c|c|}
\hline 2 & $\begin{array}{l}\text { I understand that ASWJ is the group } \\
\text { that follows the path accepted by } \\
\text { Allah, which teaching always } \\
\text { preserving unity and harmony. }\end{array}$ & 0 & 0 & $\begin{array}{c}8 \\
3.4\end{array}$ & $\begin{array}{c}45 \\
19.1\end{array}$ & $\begin{array}{l}183 \\
77.5\end{array}$ & 4.742 & Very High \\
\hline 3 & $\begin{array}{l}\text { I believe the group that follows ASWJ } \\
\text { aqeedah is the right group in this } \\
\text { world and will be saved in the } \\
\text { hereafter. }\end{array}$ & 0 & 0 & $\begin{array}{c}8 \\
3.4\end{array}$ & $\begin{array}{c}43 \\
18.2\end{array}$ & $\begin{array}{l}185 \\
78.4\end{array}$ & 4.750 & Very High \\
\hline 4 & $\begin{array}{l}\text { I know that there are many divisions } \\
\text { of aqeedah school of thoughts } \\
\text { (Example: Syiah, Batiniah) }\end{array}$ & 0 & 0 & $\begin{array}{l}11 \\
4.7\end{array}$ & $\begin{array}{c}62 \\
26.3\end{array}$ & $\begin{array}{l}163 \\
69.1\end{array}$ & 4.644 & Very High \\
\hline 5 & $\begin{array}{l}\text { I know Abu Hasan al-Asy ari and } \\
\text { Abu Mansur al-Maturidi as the two } \\
\text { main ASWJ figures, whom are } \\
\text { followed by Malaysian Muslims }\end{array}$ & 0 & $\begin{array}{c}4 \\
1.7\end{array}$ & $\begin{array}{c}27 \\
11.4\end{array}$ & $\begin{array}{c}68 \\
28.8\end{array}$ & $\begin{array}{r}137 \\
58.1\end{array}$ & 4.432 & Very High \\
\hline 6 & $\begin{array}{l}\text { I firmly believe with the Six Articles } \\
\text { of Faith }\end{array}$ & 0 & 0 & $\begin{array}{c}6 \\
2.5\end{array}$ & $\begin{array}{l}18 \\
7.6\end{array}$ & $\begin{array}{l}212 \\
89.8\end{array}$ & 4.873 & Very High \\
\hline 7 & $\begin{array}{c}\text { I consistently observe the Five Pillars } \\
\text { of Islam (Shahadah, Prayer, Fasting, } \\
\text { Alm-giving and Performing } \\
\text { Pilgrimage) }\end{array}$ & 0 & $\begin{array}{c}1 \\
0.4\end{array}$ & $\begin{array}{c}9 \\
3.8\end{array}$ & $\begin{array}{c}61 \\
25.8\end{array}$ & $\begin{array}{l}165 \\
69.9\end{array}$ & 4.653 & Very High \\
\hline 8 & $\begin{array}{l}\text { I habitually practice the noble morals } \\
\text { similarly to the morals portrayed by } \\
\text { Rasulullah SAW and his companions. }\end{array}$ & 0 & $\begin{array}{c}3 \\
1.3\end{array}$ & $\begin{array}{l}17 \\
7.2\end{array}$ & $\begin{array}{l}105 \\
44.5\end{array}$ & $\begin{array}{l}111 \\
47.0\end{array}$ & 4.373 & Very High \\
\hline 9 & $\begin{array}{l}\text { I enjoining good and forbidding } \\
\text { wrong }\end{array}$ & 0 & $\begin{array}{c}3 \\
1.3\end{array}$ & $\begin{array}{l}21 \\
8.9\end{array}$ & $\begin{array}{c}97 \\
41.1\end{array}$ & $\begin{array}{l}115 \\
48.7\end{array}$ & 4.373 & Very High \\
\hline 10 & $\begin{array}{c}\text { I do not simply label a muslim as an } \\
\text { infidel or subject him/her to killing } \\
\text { without any acceptable reason }\end{array}$ & 0 & $\begin{array}{c}1 \\
0.4\end{array}$ & $\begin{array}{c}9 \\
3.8\end{array}$ & $\begin{array}{c}71 \\
30.1\end{array}$ & $\begin{array}{l}155 \\
65.7\end{array}$ & 4.610 & Very High \\
\hline & Overall Mean & & & & & & 4.620 & Very High \\
\hline
\end{tabular}

Part C presents the findings that identifies students proficiency level in ASWJ methodologies. Table 4 illustrates the mean score derived is very high; 4.31 .

Table 4: Data Tabulation on Ahli Sunnah Wal Jamaah Aqeedah Methodology

\begin{tabular}{|c|c|c|c|c|c|c|c|c|}
\hline NO & ITEM & $\begin{array}{c}\text { VD } \\
\%\end{array}$ & $\begin{array}{l}\mathrm{D} \\
\%\end{array}$ & $\begin{array}{c}\mathrm{NS} \\
\%\end{array}$ & $\begin{array}{l}\mathrm{A} \\
\%\end{array}$ & $\begin{array}{c}\text { VA } \\
\%\end{array}$ & Mean & Interpretation \\
\hline 1 & $\begin{array}{l}\text { I use Al-Quran and } \mathrm{Al} \mathrm{Hadith} \text { as the } \\
\text { sources of reference for explaining } \\
\text { aqeedah matters. }\end{array}$ & 0 & 0 & $\begin{array}{l}12 \\
5.1\end{array}$ & $\begin{array}{c}50 \\
21.2\end{array}$ & $\begin{array}{c}174 \\
73.7\end{array}$ & 4.686 & Very High \\
\hline 2 & $\begin{array}{l}\text { I use aql as a tool to assist me in } \\
\text { understanding and accept aqeedah that } \\
\text { is sourced from Al-Quran and Sunnah. }\end{array}$ & $\begin{array}{c}1 \\
0.4\end{array}$ & $\begin{array}{c}5 \\
2.1\end{array}$ & $\begin{array}{l}20 \\
8.5\end{array}$ & $\begin{array}{c}61 \\
25.8\end{array}$ & $\begin{array}{l}149 \\
63.1\end{array}$ & 4.492 & Very High \\
\hline 3 & $\begin{array}{l}\text { ASWJ aqeedah integrates naql and aql } \\
\text { as the basis of truth in understanding } \\
\text { aqeedah. }\end{array}$ & 0 & $\begin{array}{c}3 \\
1.3\end{array}$ & $\begin{array}{l}22 \\
9.3\end{array}$ & $\begin{array}{c}76 \\
32.2\end{array}$ & $\begin{array}{c}135 \\
57.2\end{array}$ & 4.453 & Very High \\
\hline 4 & $\begin{array}{l}\text { I prioritize revelation if there is a } \\
\text { contradiction between revelation and } \\
\text { aql. }\end{array}$ & 0 & 0 & $\begin{array}{c}35 \\
14.8\end{array}$ & $\begin{array}{c}80 \\
33.9\end{array}$ & $\begin{array}{l}121 \\
51.3\end{array}$ & 4.364 & Very High \\
\hline 5 & $\begin{array}{l}\text { I use aql arguments that have been } \\
\text { agreed by ASWJ e.g obligatory, } \\
\text { impossible and neutral }\end{array}$ & 0 & $\begin{array}{c}1 \\
0.4\end{array}$ & $\begin{array}{c}24 \\
10.2\end{array}$ & $\begin{array}{c}100 \\
42.4\end{array}$ & $\begin{array}{c}111 \\
47.0\end{array}$ & 4.360 & Very High \\
\hline 6 & $\begin{array}{l}\text { I stand by the traditional law, admitting } \\
\text { the causal relationship however it leaves } \\
\text { to the mercy of Allah SWT (e.g. to } \\
\text { consume medicines as an effort to get } \\
\text { healthier, nevertheless it is upon Allah } \\
\text { mercy to heal the sickness) }\end{array}$ & $\begin{array}{c}1 \\
0.4\end{array}$ & 0 & $\begin{array}{c}17 \\
7.2\end{array}$ & $\begin{array}{c}75 \\
31.8\end{array}$ & $\begin{array}{l}143 \\
60.6\end{array}$ & 4.521 & Very High \\
\hline
\end{tabular}




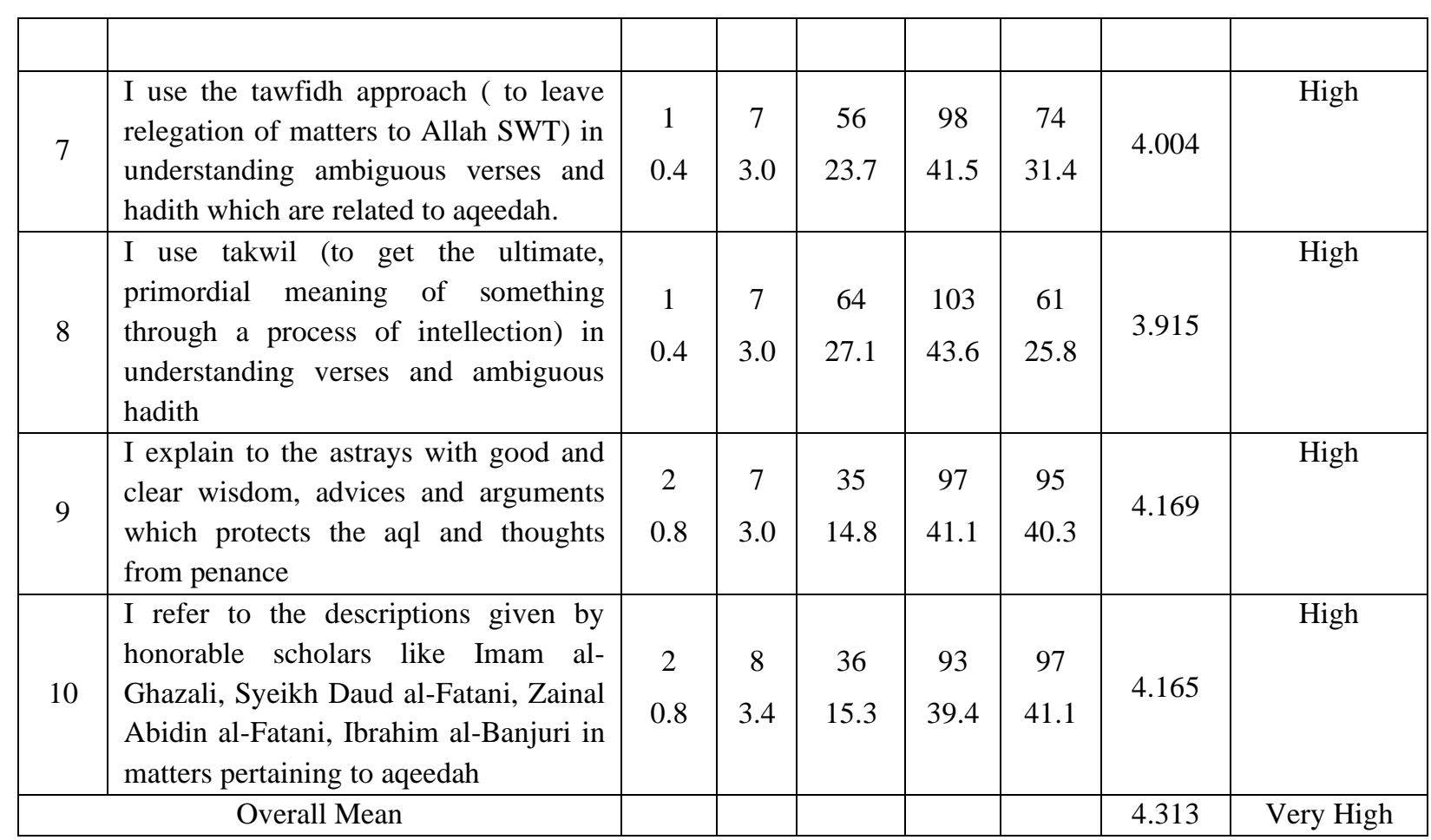

\section{Findings Discussion}

The proficiency towards the ASWJ background, characteristics and methodologies are the main aspects of Malaysian Muslim students aqeedah. It can form unity and uniformity which ultimately lead to a harmonious community. The overall findings shows that UTHM diploma students have a very high proficiency level towards ASWJ background, characteristics and methodologies.

A majority number of students agreed with the five items related to the background that gives overview about ASWJ. The item that stated ASWJ as the aqeedah that follows the teaching of Rasulullah SAW and majority of his companions had a very high mean score; 4.75 . On the other hand, there were 9 out of 236 students who chose "Not Sure" for the said item. Despite students knowledge about the two prominent figures in ASWJ , namely, Abu Hasan al-Asy'ari dan Abu Mansur al-Maturidi are considerably very high, there were 27 students who were not sure and 4 did not agree with the item. Evidently, this shows that a minority number of students do not know the true position of ASWJ aqeedah and do not know the figures responsible in compiling ASWJ aqeedah that have been followed by Malaysian Muslims.

Next, the findings about ASWJ important features; item regarding belief in the Six articles of Iman recorded a very high mean score (4.87) compared to item that noted on ASWJ background and characteristics. Thus, it shows that students mastered the ASWJ aqeedah that becomes a forefront against deviated beliefs. Nevertheless, there were 6 out of 236 students (2.5\%) who were not sure about the six articles of faith. The number have been otherwise small but the responsibility to have a firm belief in aqeedah is a fardh ain (compulsory) for every individual. Having faith in all the six articles is very important as it determines the practice and moral of a Muslim. Although there were 9 students who were not sure and 1 did not agree about their observation of Five Pillars of Islam, the items depicts a relatively very high mean score (4.65). Nevertheless, this matter has to be given attention because observation of the five pillars is a second most important basis of a Muslim after aqeedah.

ASWJ methodologies adopts Al-Quran and Al-Hadith as the main sources of reference in explaining matters regarding aqeedah scored a very high mean (4.68) compared to other items. Nonetheless, there were a relatively small number of students who still have a lack of mastery. As for the item on making aql as a tool to assist in understanding and accepting aqeedah, 20 students were not sure and 5 did not agree and 1 stated very disagree. ASWJ aqeedah integrates revelation and aql as the basis of truth in understanding aqeedah; 22 students were not sure, 3 did not agree. The item that followed is about prioritizing the revelation if there is a contradiction between revelation and aqeedah; 35 students were not sure of the item. Lastly, the item that touched on the use of aql arguments as agreed by ASWJ in understanding the aqeedah matters like compulsory, impossible and neutral denoted 24 students who were not sure and 1 did not agree. The findings rather indicate that a small portion of UTHM diploma students still could not identify the role of aql in the discussion of aqeedah. This situation could make them prone to the danger of liberalism which puts logic as a foundation in solving matters in life including religious matters and aqeedah.

Meanwhile in the aspect of understanding the verses and ambiguous hadith that highlight on the nature of Allah SWT; the mean score of using the tawfidh approach recorded a very high score (4.00). Similarly, the use of takwil approach also reported a very high score too (3.91). This has given a lead that students do not master the important 
methodology in the discussion of divinity which are employed by Asy. Though it is not the intention to brand those who use different approach in aqeedah discussion as disbelievers, the approach however is employed by ASWJ, Asya'irah stream(Khairi Jalauddin, 2019). UTHM Diploma students should master the methodology for the study at tertiary level are exposed to the discussion of aqeedah in an open manner. For that reason, their proficiency can serve as a guide and shield against different school of thoughts which are strayed from ASWJ.

\section{Summary}

However, in completing the process of consolidating ASWJ aqeedah among students, the teaching and learning of the Introduction of Islamic Studies course have to be refined in order to close the gaps in several important features. In addition, the ASWJ aqeedah reinforcement programmes conducted by the Johor Islamic Council, UTHM Islamic Centre and ASWJ Institute also need to be further detailed. Amongst the main discussion in ASWJ are the significant important of knowing the background of Abu Hasan Al-Asya'ri and al-Maturidi as ASWJ prominent figures, articles of faith and pillars of Islam and ASWJ good morals conduct and preserving the relationship among Muslims by not easily labelling someone as a disbeliever should there be any conflicting opinion in aqeedah. In terms of ASWJ aqeedah, focus has to be put on the 20 mandatory nature of Allah SWT that noted on verses and ambigous hadith and methodology in confronting the heretics. Students proficiency at university level in the above mentioned aspects are able to strengthen ASWJ aqeedah as well as prepare students to confront the groups that are deviated from ASWJ aqeedah.

\section{Appreciation}

The authors would like to express their appreciation to Research Management Centre, Universiti Tun Hussein Onn Malaysia for funding this research through H260 TIER 12018 grant.

\section{Refrences}

1. Abd al-Qahir bin Tahir Muhammad al-Baghdadi. (2013). al-Farq Baina al-Firaq, Beirut: Dar al-Kutub alIlmiyah h.19

2. Abdul Hamid @ Yusoff bin Yunus. (2005), Mengenal Ahli Sunnah Wal Jamaah, Jabatan Kemajuan Islam Malaysia

3. Adam Badhrulhisham. (2016). Ahli Sunnah Wal Jamaah dan Pemakaiannya di Malaysia: isu dan Cabaran, Jurnal `Ulwan, Jilid 1 2016, h. 128-149

4. Alias Baba, 1999, Statistik Penyelidikan dalam Pendidikan dan Sains Sosial. Bangi: Universiti Kebangsaan Malaysia

5. Di Malaysia, Persidangan Antarabangsa Tokoh Ulama Melayu Nusantara 2019 ke-3 Hotel Grand Blue Wave Shah Alam, Selangor. 22 Oktober 2019.

6. Engku Ahmad Zaki Engku Alwi (.t.t.), Definisi Ahl al-Sunnah Wa al-Jama'ah: Satu Analisis, eJournal, Kuala Lumpur, Universiti Malaya, h. 1-22

7. Hamidi Ismail, 2020, Metodologi Pengajian Akidah Ahli Sunnah Wal Jama'ah: Referensi Khas Kepada Manhaj Al-Asha'irah, h. 20-21dicapai daripada https://www.researchgate.net/publication/338594393

8. Johari bin Mat, (t.t.), Ahl Sunnah Wal Jama'ah; Satu Pengenalan, eJournal, Kuala Lumpur; Universiti Malaya, h. 1-22

9. Khairi Jalalluddin \& Khadijah Abdul Razak, Pendidikan Akidah Asas Pembinaan Tamadun Islam

10. Khairul Hamimah binti Mohammad Jodi. (2008), Pemahaman Akidah Di Kalangan Pelajar Institut Pengajian Tinggi Swasta Dan Kesannya Terhadap Masalah Akhlak : Suatu Kajian, Semeanar Kebangsaan Kemahiran Insaniah \& Kesejahteraan Sosial 2008

11. Mohd Aizam bi Mas’od, 2013, Diskusi Isu Aqeedah dan Pemikiran Semasa di Malaysia, Jabatan Kemajuan Islam Malaysia, h. 25-26

12. Mohd Shafiee bin Hamzah, Azli Fairuz bin Laki, Rahimah binti Embong, Nik Murshidah Nik Din, 2015, Penerapan Akidah Dalam Dasar Pendidikan Malaysia: Analisis Terhadap Falsafah Pendidikan Negara dan Islam Hadhari, Jurnal Islam dan Masyarakat Kontemporari Bil. 9 Januari 2015, Universiti Sultan Zainal Abidin, h. 1-11

13. Muhammad Abd al-Hadi, 1998, Ahl alSunnah Wa al-Jama'ah Mu'alim al-Intiqalah al-Kubra, cet. 4, Riyad: Dar Tayyibah, h.80

14. Muhammad Usman El-Muhammady. (2010). Perpecahan Menghakis Pengaruh Kekuatan Islam, Kertas Kerja Multaqa Ulama' dan Ilmuan Johor 1431H/2010M, h. 50

15. Muhyiddin Abdusshomad, K.H., (2009), iAqeedah AhlussunnahWaljama`ah, Terjemahan dan syarah 'Aqeedah al-'Awam, Surabaya: Khalista, h. 8-9

16. Sirajuddin Abbas K.H., (2016), I’itiqad Ahlussunnah Wal-Jama'ah, Kelantan: Pustakan Aman Press Sdn. Bhd., 2-3

17. Zakaria Stapa (Prof. Dato'), 2015, Keutuhan Ahli Sunnah WalJamaah (ASWJ) Di Malaysia dalam Memartabatkan Agma Islam, dibentangkan dalam Semeanar Ahli Sunnah Wal Jamaah: Pengukuhan Akidah Menurut Manhaj Wasatiyyah, pada 28 Oktober 2015 
Shakila Ahmad ${ }^{a}$, Sharifah Khadijah Syed Abu Bakar ${ }^{b}$, Harliana Abd. Halim ${ }^{c}$, Intan Farhana Saparuddin ${ }^{d}$, Abdullah Sulaiman $^{e}$, Halimi Mohd. Khalid ${ }^{f}$, Nur Zainatul Nadra Zainol ${ }^{g}$, and Siti Marpuah ${ }^{h}$ 